\title{
Pengaruh Model Pembelajaran Kooperatif Tipe Student Team Achievement Division Terhadap Hasil Belajar Matematika Siswa Kelas VII SMP Kesehatan Mandonga
}

\author{
(The Effect Of Cooperative Learning Model Type Student Team Achievement Division On
} Mathematics Learning Outcomes Of Grade VII Student's Of SMP Kesehatan Mandonga)

\author{
Wa Ode Nurmila ${ }^{1}$, Kadir $^{2}$, Muhammad Sudia ${ }^{2}$, Rahmad Prajono ${ }^{3}$ \\ ${ }^{1}$ Alumnus Jurusan Pendidikan Matematika FKIP Universitas Halu Oleo; Co-author: nurmila.w@yahoo.com \\ ${ }^{2}$ Dosen Pendidikan Matematika FKIP dan PPS Universitas Halu Oleo \\ ${ }^{3}$ Dosen Pendidikan Matematika FKIP Universitas Halu Oleo
}

\begin{abstract}
Abstrak: Penelitian ini bertujuan untuk: (1) mendeskripsikan hasil belajar matematika siswa yang diajar dengan model pembelajaran kooperatif tipe STAD, (2) mendeskripsikan hasil belajar matematika siswa kelas yang diajar dengan model pembelajaran konvensional, dan (3) untuk mengetahui apakah ada pengaruh model pembelajaran tipe STAD terhadap hasil belajar matematika siswa kelas VII SMP Kesehatan Mandonga. Sampel diambil secara purposive sampling. Teknik pengumpulan data dilakukan dengan pemberian instrumen penelitian berupa lembar observasi dan tes berbentuk uraian. Teknik analisis data menggunakan statistik deskriptif dan statistik inferensial. Penelitian ini menghasilkan: (1) Rata-rata persentase ketelaksanaan pembelajaran oleh guru sebesar $81 \%$ dan aktivitas belajar siswa mencapai $83,33 \%$, (2) rata-rata proses pelaksanaan pembelajaran dengan model pembelajaran konvensional dengan rata-rata persentase oleh guru sebesar 79\% dan aktifitas belajar siswa mencapai 77\%; (3) rata-rata hasil belajar matematika siswa yang pembelajaran menggunakan model pembelajaran kooperatif tipe STAD adalah 66.90; (4) rata-rata hasil belajar matematika siswa yang pembelajaran menggunakan model pembelajaran konvensional adalah 55,26; dan (5) Terdapat pengaruh yang signifikan penggunaan model pembelajaran kooperatif tipe STAD terhadapa hasil belajar matematika siswa
\end{abstract}

Kata kunci: Hasil Belajar Matematika, STAD, Model pembelajaran Kooperatif.

\begin{abstract}
This research aims to: (1) describe the mathematics learning outcomes of students taught by the STAD type cooperative learning model, (2) describe the mathematics learning outcomes of class students who are taught using conventional learning models, and (3) to find out whether there are influences of type learning models STAD on the mathematics learning outcomes of class VII students of SMP Mandonga. The sample was taken by purposive sampling. The technique of data collection is done by giving research instruments in the form of observation sheets and test descriptions. The data analysis technique uses descriptive statistics and inferential statistics. This study resulted in: (1) The average percentage of teacher learning implementation by $81 \%$ and student learning activities reached $83.33 \%$, (2) the average process of implementing learning with conventional learning models with an average percentage by teachers of $79 \%$ and student learning activities reach 77\%; (3) the average mathematics learning outcomes of students who are learning using the STAD type cooperative learning model is 66.90; (4) the average mathematics learning outcomes of students whose learning using conventional learning models is 55.26; and (5) There is a significant influence on the use of the STAD type cooperative learning model on student mathematics learning outcomes
\end{abstract}

Keywords: Mathematics Learning Outcomes, STAD, Cooperative Learning Model

\section{PENDAHULUAN}

Matematika sebagai salah satu bidang studi yang sangat mendukung perkembangan ilmu pengetahuan dan teknologi, memiliki peran yang sangat penting dalam bidang pendidikan. Hal ini disebabkan karena matematika sangat berkaitan dengan bidang studi lain serta kehidupan sehari-sehari, sehingga pelajaran matematika diberikan disemua jenjang pendidikan mulai dari pendidikan dasar, pendidikan menengah, dan sebagian perguruaan tinggi. 
Salah satu mata pelajaran yang mempunyai hasil belajar rendah di sekolah adalah matematika. Mata pelajaran ini termasuk mata pelajaran yang kurang diminati oleh siswa, karena untuk dapat memahami materi yang terkadang didalamnya perlu adanya kejelian dalam berfikir, ketelitian dalam pengajaran, dan waktu yang cukup untuk mengadakan latihan-latihan, baik pada jam pelajaran maupun di luar jam pelajaran.

Arikunto (2006: 52) menyatakan hasil belajar adalah hasil yang diperoleh siswa yang biasanya dinyatakan dalam bentuk angka, huruf, atau kata. Menurut sudjana (2004: 25), "hasil belajar adalah kemampuan-kemampuan yang dimiliki siswa setelah ia menerima pengalaman belajarnya. Menurut Sudjana dalam Maria (2015: 9), hasil belajar adalah kemampuan yang dimiliki siswa setelah menerima pengalaman belajar.

Upaya untuk memperoleh hasil belajar dapat dilakukan evaluasi atau penilaian yang merupakan tindak lanjut atau cara untuk mengukur tingkat penguasan siswa. Kemajuan prestasi belajar siswa tidak saja diukur dari tingkat penguasan ilmu pengetahuan tetapi juga sikap dan keterampilan. Dengan demikian penilain hasil belajar siswa mencakup segala hal yang dipelajari di sekolah, baik itu menyangkut pengetahuan, sikap dan keterampilan (Jihad dan Haris, 2013: 15).

Banyak faktor yang mempengaruhi tinggi rendahnya hasil belajar siswa di kelas, salah satunya adalah model pembelajaran yang digunakan oleh guru. Berdasarkan hasil observasi awal di SMP Kesehatan Mandonga terlihat bahwa dalam proses pembelajaran, guru masih menggunakan model pembelajaran konvensional. Dalam proses pembelajaran, guru mendominasi pelaksanaan proses pembelajaran dan jarang terlihat siswa aktif dalam pembelajaran. Hal ini berakibat pada rendahnya hasil belajar matematika siswa khususnya di kelas VII hasil wawancara dengan salah satu guru yang mengajar mata pelajaran Matematika di SMP Kesehatan Mandonga, diketahui bahwa rata-rata hasil belajar matematika siswa kelas VII masih tergolong rendah yakni $\mathrm{VII}_{\mathrm{A}}=65,94, \mathrm{VII}_{\mathrm{B}}=64,39, \mathrm{VII}_{\mathrm{C}}=$ 61,87. Hal ini disebabkan kegiatan pembelajaran matematika masih dilakukan dengan suatu proses pentransferan konsep materi, bukan proses membelajarkan siswa. Akibatnya tingkat pemahaman dan pengetahuan yang diperoleh siswa rendah. Pengetahuan yang diperoleh siswa hanya bersifat hafalan tanpa memahami materi yang dipelajarinya. Pengetahuan hanya bertahan dalam waktu yang relatif singkat pada ingatan siswa. Secara otomatis hal itu akan mempengaruhi hasil belajar siswa. Ini merupakan suatu indikasi tingkat pemahaman konsep matematika masih sangat rendah. Hal ini disebabkan karena siswa kurang antusias atau siswa kurang memahami materi pelajaran. Selain itu, pada kreativitas siswa dalam membuat dan menyampaikan ide-idenya masih sangat rendah. Siswa kurang percaya diri khususnya pada saat menyelesaikan soalsoal yang diberikan guru.

Selama ini proses pembelajaran matematika yang digunakan masih paradigm pembelajaran satu arah, yaitu umumnya dari guru ke siswa, maka guru akan lebih mendominasi pembelajaran. Dengan demikian, pembelajaran cenderung monoton sehingga mengakibatkan siswa merasa jenuh, tersiksa, dan siswa bersifat pasif.

Fenomena di atas merupakan suatu masalah dalam pembelajaran matematika dan harus dicarikan solusi agar masalah itu tidak berkelanjutan. Guru mesti merasa bahwa ada sesuatu yang perlu diperbaiki dalam praktik pembelajaran yang dilakukanya selama ini, dan perbaikan tersebut diprakarsai dari dalam diri guru sendiri, bukan orang lain dengan tujuan memperbaiki kinerjanya sebagai guru, sehingga proses pembelajaran dapat 
berjalan dengan baik dan hasil belajar siswa meningkat.

Isjoni (2007: 51), mengungkapkan model pembelajaran kooperatif tipe STAD merupkan salah satu tipe dari pembelajaran kooperatif yang membagi siswa kedalam kelompok-kelompok kecil yang beranggotakan 4-5 siswa secara heterogen, diawali dengan penyampaian tujuan pembelajaran, menyampiakn materi, kegiatan kelompok, soal dan penghargaan kelompok.

Pada pembelajaran kooperatif tipe STAD siswa percaya bahwa keberhasilan mereka akan tercapai jika setiap anggota kelompoknya berhasil. Sistem pengajaran yang memberi kesempatan kepada siswa untuk bekerja sama dengan sesama siswa, dalam tugas-tugas yang terstruktur disebut sebagai pengajaran gotong royong. Sistem pendidikan gotong royong merupakan alternatif menarik yang dapat mencegah timbulnya keagresifan dalam sistem kompetisi dan keterasingan dalam sistem individu tanpa mengorbankan aspek kognitif (Candiasa 2015: 3).

Tujuan model pembelajaran kooperatif tipe STAD adalah memberikan peluang kepada siswa yang berbeda latar belakang dan kondisi untuk bekerja sama saling membantu satu sama lain atas tugas-tugas bersama, dan melalui penggunaan struktur penghargaan kooperatif, belajar untuk menghargai satu sama lain. Pembelajaran kooperatif mempunyai efek yang berarti terhadap penerimaan yang luas terhadap keragaman ras, budaya dan agama, strata sosial, kemampuan dan ketidak mampuan (Ibrahim, 2000: 9).

Fase-fase model pembelajaran kooperatif tipe STAD menurut Ibrahim (Anjarsari 2015: 14), dapat dilihat pada Tabel 1.

\section{Tabel 1. Fase Model Pembelajaran Kooperatif Tipe STAD}

\begin{tabular}{|c|c|}
\hline Fase Pembelajaran & Kegiatan Guru \\
\hline Fase 1 & Guru menyampaikan semua tujuan pembelajaran yang \\
\hline $\begin{array}{l}\text { Menyamapaikan tujuan dan } \\
\text { memotivasi siswa }\end{array}$ & $\begin{array}{l}\text { ingin dicapai pada pelajaran tersebut dan memotivasi } \\
\text { siswa belajar. }\end{array}$ \\
\hline Fase 2 & Guru menyajikan informasi kepada siswa dengan cara \\
\hline Menyampaikan informasi & demonstrasi atau lewat bahan bacaan. \\
\hline Fase 3 & Sebelum pembelajaran berlangsung. \\
\hline $\begin{array}{l}\text { Mengorganisasikan siswa ke } \\
\text { dalam kelompok-kelompok } \\
\text { belajar }\end{array}$ & $\begin{array}{l}\text { Guru menjelaskan kepada siswa bagaimana cara } \\
\text { membentuk kelompok agar melakukan transisi secara } \\
\text { efisien dalam belajar. }\end{array}$ \\
\hline Fase 4 & Guru membimbing kelompok-kelompok belajar pada \\
\hline $\begin{array}{l}\text { Membimbing siswa bekerja } \\
\text { dan belajar kelompok }\end{array}$ & saat mereka mengerjakan tugas mereka. \\
\hline Fase 5 & Guru mengevaluasi hasil belajar tentang materi yang \\
\hline Melakukan evaluasi & $\begin{array}{l}\text { telah dipelajari dimana masing-masing kelompok } \\
\text { mempresentasikan hasil karyanya. }\end{array}$ \\
\hline Fase 6 & Guru memberi apresiasi atau pujian sebagai penghargaan \\
\hline Memberikan penghargaan & pada upaya hasil belajar individu dan kelompok. \\
\hline
\end{tabular}

Shoimin (2016: 189), keunggulan dan kekurangan model pembelajaran kooperatif tipe STAD yaitu:
a. Adanya kerjasama dalam satu kelompok sehingga siswa saling

membantu dan memotivasi untuk berhasil bersama.

b. Memberikan kesempatan kepada siswa untuk menggunakan keterampilan bertanya dan membahas suatu masalah dalam proses kerjasama. 
c. Menempatkan siswa sebagai tutor sebaya untuk lebih meningkatkan keberhasilan kelompok.

d. Meningkatkan interaksi antar siswa aktif untuk mengembangkan rasa menghargai, menghormati pribadi temannya, dan menghargai pendapat orang lain.

e. Setiap individu merasa mendapat tugas dan tanggung jawab sendiri-sendiri sehingga pembelajaran dapat berjalan

\section{METODE PENELITIAN}

Jenis penelitian eksperimen yang digunakan adalah Quasi eksperimental design (eksperimen semu), karena tidak semua faktor yang mempengaruhi penelitian dapat dikontrol secara penuh. Penelitian ini dilakukan pada semester ganjil tahun ajaran 2018/2019 pada kelas VII SMP Kesehatan Mandonga.

Populasi dalam penelitian ini adalah seluruh siswa kelas VII SMP Kesehatan Mandonga yang terdaftar pada semester bermakna dan tujuan pembelajaran dapat tercapai secara optimal.

Kekurangan model pembelajaran kooperatif tipe STAD

a. Kontribusi dari siswa berprestasi rendah menjadi kurang.

b. Siswa berprestasi tinggi akan mengarah pada kekecewaan karena peran anggota yang pandai lebih dominan.

c. Membutuhkan waktu yang lebih lama untuk siswa sehingga sulit mencapai target kurikulum

ganjil Tahun Ajaran 2018/2019. Sampel diambil dengan purposive sampling, berdasarkan purposive sampling kelas $\mathrm{VII}_{\mathrm{A}}$ sebagai kelas eksperimen dengan menerapkan model pembelajaran kooperatif tipe STAD.

Desain penelitian yaitu Posttest Only Control Group Design. Desain penelitian ini secara visual dapat ditampilkan pada Tabel 2.

Tabel 2. Desain Penelitian

\begin{tabular}{cccc}
\hline & Group & Perlakuan & Tes \\
\hline $\mathrm{R}$ & Eksperimen $(\mathrm{E})$ & $\mathrm{X}$ & $\mathrm{Y}_{\mathrm{E}}$ \\
$\mathrm{R}$ & Kontrol $(\mathrm{K})$ & - & $\mathrm{Y}_{\mathrm{K}}$ \\
\hline
\end{tabular}

Keterangan :

$\mathrm{X} \quad$ : Perlakuan berupa penerapan model pembelajaran kooperatif tipe STAD

$\mathrm{Y}_{\mathrm{E}} \quad$ : Hasil tes pada kelas eksperimen

$\mathrm{Y}_{\mathrm{K}} \quad$ : Hasil tes pada kelas kontrol

Instrumen utama yang digunakan dalam penelitian ini lembar observasi dan tes hasil belajar matematika. Sebelum digunakan instrumen perlu validasi. Uji validitas instrumen merupakan suatu langkah pengujian yang dilakukan terhadap isi dari instrumen, dengan tujuan untuk mengukur ketetapan instrument yang digunakan dalam penelitian (Sugiyono, 2016).

Uji validitas dan reabilitas instrument penelitian yang dilakukan pada penelitian ini adah uji panelis. Analisis validitas penilaian panelis digunakan untuk mengetahui validitas konsep instrument melalui penilaian panelis dengan menggunakan rumus :

$$
V=\frac{\sum n_{i}\left|n_{i}-l_{o}\right|}{[N(c-1)]}
$$

(Arikunto, 2015: 38)

Keterangan :

$V=$ Indeks validitas isi

$n_{i}=$ Skor butir soal ke- $i$

$l o=$ Nilai skor terendah

Pengaruh Model Pembelajaran Kooperatif Tipe Student Team Achievement Division Terhadap Hasil Belajar Matematika Siswa Kelas VII SMP Kesehatan Mandongal (Wa Ode Nurmila, Kadir, Muhammad Sudia Rahmad Prajono) 
$N=$ Jumlah skor butir soal ke- $i$

$c=$ Skor maksimal butir soal

Nilai V terletak antara 0 dan 1 (valid $\geq 0,6$ ). Untuk Reliabilitas tes uraian ditentukan dengan menggunakan rumus Alpha yaitu:

$$
\mathrm{r}_{11}=\left[\frac{n}{n-1}\right]\left[1-\frac{s_{i}^{2}}{s_{t}{ }^{2}}\right]
$$

(Jihad, 2012: 180)

Keterangan:

$\mathrm{r}_{11}=$ Koefisien reliabilitas

$\mathrm{n}$ = Banyak butir soal

$s_{i}^{2}=$ Jumlah varians skor tiap item

$s_{t}^{2}=$ Varians skor total.

Rumus untuk mencari varians:

$$
s_{i}^{2}=\frac{\sum X^{2}-\frac{\left(\sum X\right)^{2}}{n}}{n}
$$

Pemberian interpretasi terhadap koefisien reliabilitas tes $\left(r_{11}\right)$ pada umumnya digunakan patokan:

$0 \leq \mathrm{r}_{11} \leq 0,20$ reliabilitas : sangat rendah

$0,20<\mathrm{r}_{11} \leq 0,40$ reliabilitas : rendah

$0,40<\mathrm{r}_{11} \leq 0,70$ reliabilitas : sedang

$0,70<\mathrm{r}_{11} \leq 0,90$ reliabilitas : tinggi

$0,90<\mathrm{r}_{11} \leq 1,00$ reliabilitas : sangat tinggi

(Ruseffendi dalam Jihad 2012: 181).

Berdasarkan hasil penilaian panelis, kemudian dilakukan perbaikan pada soal-soal yang telah dikomentari oleh panelis. Setelah dilakukan penilaian panelis dan perbaikan, kemudian soal tersebut dijadikan sebagai soal posttest dan

\section{HASIL PENELITIAN}

Hasil observasi pelaksanaan pembelajaran dengan model pembelajaran kooperatif tipe STAD oleh guru pada kelas eksperimen yang tersaji pada Tabel 3 berikut bahwa pelaksanaan pembelajaran matematika dengan menggunakan model pembelajaran kooperatif tipe STAD oleh guru dikelas pada materi Bilangan Pecahan, keberhasilan pengelolaan pembelajaran pada pertemuan pertama tingkat keberhasilan sebesar $66,6 \%$ ini termasuk dalam kategori sedang. untuk reliabiltas tes yang akan digunakan pada penelitian ini yaitu $\mathrm{r}_{11}>0,40$.

Analisis data yang dilakukan dengan menggunakan teknik statistik yaitu statistik deskriptif dan statistik inferensial. Statistik deskriptif dilakukan untuk mendiskripsikan nilai yang diperoleh masing-masing kelas dalam bentuk nilai rata-rata, nilai maksimum, nilai minimum dan standar deviasi. Analisis statistik inferensial dimaksudkan untuk menguji hipotesis penelitian. Sebelum pengujian hipotesis, maka terlebih dahulu dilakukan pengujian prasyarat analisis yaitu uji normalitas dan uji homogenitas data sebagai uji prasayaratnya.

Uji normalitas dalam penelitian ini akan dianalasis menggunakan tes Kolmogorov-Sminov dengan bantuan SPSS (Statistical Product and Service Solution) dengan tingkat signifikansi 0,05. Populasi data dikatakan terdistribusi secara normal apabila hasil tes Kolmogorov-Sminov (p) > 0,05, jika hasil tes Kolmogorov-Sminov ( $\mathrm{p}) \leq 0,05$ maka data tidak berdistribusi normal (Sujarweni, 2015: 55).

Uji homogenitas digunakan statistik uji Levene dengan kriteria pengambilan keputusan sebagai berikut: Jika nilai Sig > $\alpha=0,05$ berarti kedua kelompok memiliki varians yang homogen. Jika nilai Sig $\leq \alpha=$ 0,05 berarti kedua kelompok memiliki varians yang tidak homogen.

Pelaksanaan pembelajaran pada pertemuan kedua sampai pertemuan keenam mengalami peningkatan yang sangat baik. Pelaksanaan pembelajaran pada pertemuan kedua mengalami peningkatan yang lebih baik dibanding pada pertemuan pertama. Tingkat keberhasilan skor terlaksana pembelajaran 11 dengan tingkat keberhasilan mencapai (73,3\%). Selanjutnya pada pertemuan ketiga, tingkat keberhasilan pelaksanaan pembelajaran masih meningkat dari 
pertemuan kedua yaitu terlaksana sebesar 13 dengan persentase $(86,6 \%)$. Pada pertemuan keempet tingkat keberhasilan pelaksanaan pembelajaran menurun menjadi 12 terlaksana dengan persentase yaitu sebesar (80\%). Pada pertemuan kelima tingkat keberhasilan masih meningkat dan dikatakan cukup baik yaitu terlaksana sebesar 13 dengan persentase $(86,6 \%)$. Selanjutnya pada pertemuan keenam guru sudah bisa menerapkan semua tahapan-tahapan pembelajaran dengan baik sehingga ketercapaian pelaksanaan pembelajaran mencapai poin
14 dengan persentase sebesar (93,3\%). Secara keseluruhan, peneliti telah melaksanakan rangkaian kegiatan pembelajaran dengan model pembelajaran kooperatif tipe STAD dan sebelumnya telah merefleksi kekurangan pada saat kegiatan pembelajaran pertemuan pertama. Begitu pula pertemuan kedua sampai keenam, mamperlihatkan peningkatan ketercapaian seluruh aspek yang diamati, karena siswa maupun peneliti sudah dapat menyelesaikan diri dengan proses pembelajaran yang baru yaitu model pembelajaran kooperatif tipe STAD.

Tabel 3. Deskripsi Keberhasilan Pengelolaan Pembelajaran oleh Guru pada Kelas Eksperimen

\begin{tabular}{ccc}
\hline Pertemuan & Skor Terlaksana & Persentase $(\%)$ \\
\hline 1. & 10 & $66,6 \%$ \\
2. & 11 & $73,3 \%$ \\
3. & 13 & $86,6 \%$ \\
4. & 12 & $80 \%$ \\
5. & 13 & $86,6 \%$ \\
6. & 14 & $93,3 \%$ \\
\hline
\end{tabular}

Hasil observasi pelaksanaan pembelajaran dengan model pembelajaran

kelas eksperimen dapat dilihat pada Tabel kolaboratif tipe STAD oleh siswa pada

4.

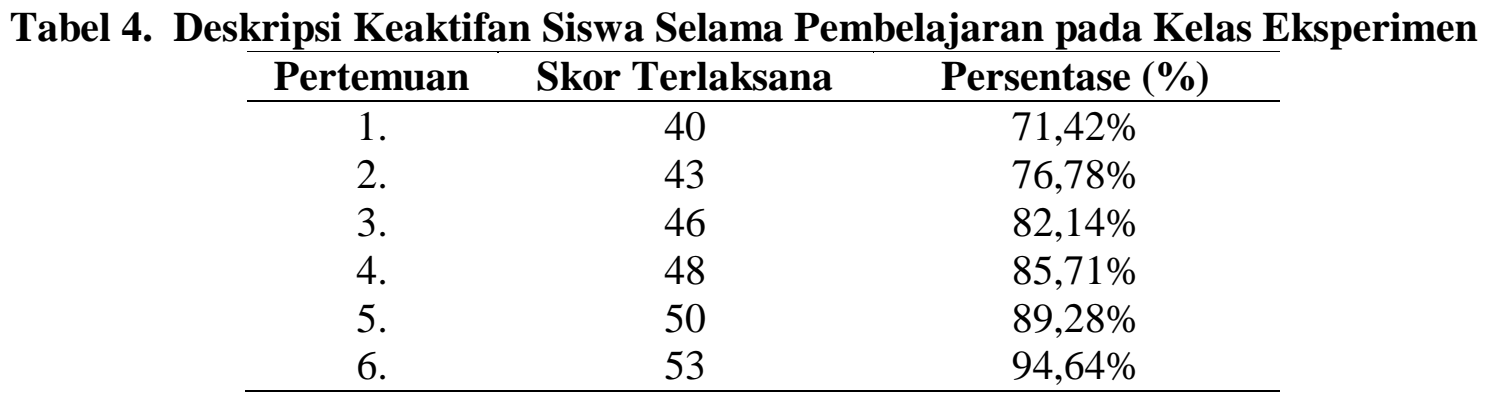

Berdasarkan Tabel 4. hasil observasi aktivitas siswa dalam pelaksanaan pembelajaran dengan menggunakan model pembelajaran kooperatif tipe STAD pada materi bilangan pecahan, pada pertemuan pertama, ketercapaian dari seluruh aspek yang diamati sebesar 40 dengan persentase adalah $(71,42 \%)$ yang berarti bahwa keaktifan siswa pada pertemuan pertama tergolong baik. Pertemuan kedua tingkat ketercapaian siswa mengalami peningkatan yaitu mencapai 43 dengan persentase sebesar $76,78 \%$ ini termaksud pencapaian yang baik. Pada pertemuan ketiga kembali mengalami peningkatan ketercapaian yaitu sebesar 46 dengan persentase sebesar $82,14 \%$. Pertemuan keempat sampai keenam memperlihatkan ketercapaian aspek yang diamati yaitu 48, 50 , dan 53 dengan persentase berturut- 
turut adalah 85,71\%, 89,28, 96,64\% Secara umum, ketercapaian keseluruhan aspek yang diamati pada pertemuan keempat sampai keenam mengalami peningkatan jika dibandingkan dengan pelaksanaan pada pertemuan pertama.Pada pertemuan keempat sampai keenam ini, siswa sudah mulai terbiasa dengan pembelajaran yang dilakukan secara berkelompok dengan menggunakan model pembelajaran kooperatif tipe STAD. Berdasarkan uraian diatas dapat di simpulkan bahwa siswa juga memerlukan waktu untuk beradaptasi terhadap suatu pembelajaran yang mereka anggap baru.

Hasil observasi pelaksanaan pembelajaran dengan model pembelajaran konvensional oleh guru pada kelas kontrol dapat dilihat pada Tabel 5.

Tabel 5. Deskripsi Keberhasilan Pengelolaan Pembelajaran oleh Guru pada Kelas

Kontrol

\begin{tabular}{ccc}
\hline Pertemuan & Skor Terlaksana & Persentase (\%) \\
\hline 1. & 8 & $66,6 \%$ \\
2. & 9 & $75 \%$ \\
3. & 9 & $75 \%$ \\
4. & 10 & $83,3 \%$ \\
5. & 10 & $83,3 \%$ \\
6. & 11 & $91,6 \%$ \\
\hline
\end{tabular}

Berdasarkan hasil observasi pada Tabel 5. dengan menggunakan model pembelajaran konvensional oleh guru dikelas kontrol pada materi bilangan pecahan, keberhasilan pengelolaan pembelajaran pada pertemuan pertama sudah baik dengan tingkat keberhasilan terlaksana pembelajaran siswa 8 dengan presentase sebesar $(66,6 \%)$. Namun pada pertemuan pertama peneliti masih menyesuaikan kondisi siswa dengan model pembelajaran yang di terapkan di kelas kepada siswa. Pertemuan kedua tingkat ketercapaian mengalami peningkatan mencapai $75 \%$ ini termaksud pencapaian yang baik. Namun pada pertemuan ketiga tingkat ketercapaian masih tetap sama hanya sebesar $75 \%$. Pertemuan keempat sampai keenam memperlihatkan persentase berturut-turut adalah 83,3\%, 83,3\%, 91,6\%. Secara umum, ketercapaian keseluruhan aspek yang diamati pada pertemuan keempat sampai keenam mengalami peningkatan jika dibandingkan dengan pelaksanaan pada pertemuan pertama.

Hasil observasi pelaksanaan pembelajaran dengan model pembelajaran konvensional oleh siswa pada kelas kontrol dapat dilihat pada Tabel 6 .

Tabel 6. Deskripsi Keaktifan Siswa Selama Pembelajaran pada Kelas Kontrol
\begin{tabular}{cccc} 
Pertemuan & Skor Terlaksana & Persentase (\%) \\
\hline 1. & 30 & $66,6 \%$ \\
2. & 33 & $68,7 \%$ \\
3. & 36 & $72,9 \%$ \\
4. & 38 & $79 \%$ \\
5. & 40 & $83,3 \%$ \\
6. & 44 & $91,6 \%$ \\
\hline
\end{tabular}

Berdasarkan hasil observasi pada Tabel 6. hasil observasi pelaksanaan pembelajaran dengan menggunakan model pembelajaran konvensional oleh siswa dikelas kontrol pada materi bilangan pecahan, keberhasilan pengelolaan 
pembelajaran pada pertemuan pertama sudah baik dengan tingkat keberhasilan skor terlaksana sebesar 30 dengan presentase $(66,6 \%)$. Namun pada pertemuan pertama peneliti masih menyesuaikan kondisi siswa dengan model pembelajaran yang di terapkan di kelas kepada siswa.

Pertemuan kedua tingkat ketercapaian dengan presentase sebesar $68,7 \%$ ini termaksud pencapaian yang baik. Pertemuan ketiga sampai keenam memperlihatkan ketercapaian dengan persentase berturut-turut adalah 72,91\%, $79 \%, 83,3 \%, 91,6 \%$. Secara umum, ketercapaian keseluruhan aspek yang diamati pada pertemuan ketiga sampai keenam mengalami peningkatan jika dibandingkan dengan pelaksanaan pada pertemuan pertama.Hal tersebut dapat dilihat dari peningkatan presentase ketercapaian aspek yang diamati pada setiap pertemuan.

Data kuantitatif diperoleh dari tes hasil belajar matematika siswa dengan menggunakan model pembelajaran kooperatif tipe STAD di kelas. Setelah pembelajaran selesai dilaksanakan, diberikan tes untuk mengetahui hasil belajar matematika siswa pada materi Bilangan pecahan sehingga diperoleh nilai untuk mengetahui peningkatan hasil belajar matematikasiswa setelah pembelajaran dilaksanakan.

Ukuran statistik data diperoleh dari analisis data tes hasil belajar matematika siswa yang dilaksanakn dikelas $\mathrm{VII}_{\mathrm{A}}$ dan $\mathrm{VII}_{\mathrm{B}}$. Analisis deskriptif dengan menggunakan bantuan SPSS diperoleh data hasil belajar siswa pada tabel berikut.

Tabel 7. Statistik Deskriptif Hasil Belajar Matematika Siswa Descriptive Statistics

\begin{tabular}{|c|c|c|c|c|c|c|}
\hline & $\mathbf{N}$ & Minimum & Maximum & Mean & $\begin{array}{c}\text { Std. } \\
\text { Deviation } \\
\end{array}$ & Variance \\
\hline K_Eksperimen & 32 & 28,50 & 95,00 & 66,9047 & 17,2897 & 298,934 \\
\hline K_Kontrol & 31 & 25,00 & 85,71 & 55,2635 & 16,9603 & 287,653 \\
\hline Valid N (Listwise) & 31 & & & & & \\
\hline
\end{tabular}

Sumber: Data Primer Diolah dengan SPSS

Hasil analisis deskriptif pada kelas eksperimen sebagaimana disajikan pada Tabel 7. diperoleh nilai terendah 28,50 dan nilai tertinggi 95,00 , nilai rata-rata 66,90 , standar deviasi 17,28 dan varians 298,934. Dan hasil analisis deskripsi pada kelas kontrol diperoleh nilai terendah 25,00 dan nilai tertinggi 85,71 , standar deviasi 16,96 dan varians 287,653 .

Sebelum dilakukan pengujian hipotesis, terlebih dahulu dilakukan uji normalitas. Uji normalitas data dilakukan sebagai prasyarat untuk melakukan uji hipotesis yang dimaksudkan untuk mengetahui apakah data berasal dari populasi yang berdistribusi normal atau tidak. Hal ini diperlukan dalam rangka penentuan jenis metode analisis data yang digunakan.

Populasi data dikatakan terdistribusi secara normal apabila hasil tes Kolmogorov-Smirnov (p) $>0,05$, jika hasil tes Kolmogorov-Smirnov (p) $<0,05$ maka diinterpretasikan bahwa data tidak normal Untuk keperluan ini maka statistik yang digunakan adalah uji KolmogorovSmirnov pada data tes akhir. Hasil perhitungannya dapat dilihat pada Tabel 8 . 
Tabel 8. Hasil Analisis Statistik Uji Normalitas Data Hasil Belajar Matematika Siswa pada Kelas Eksperimen dan Kelas Kontrol

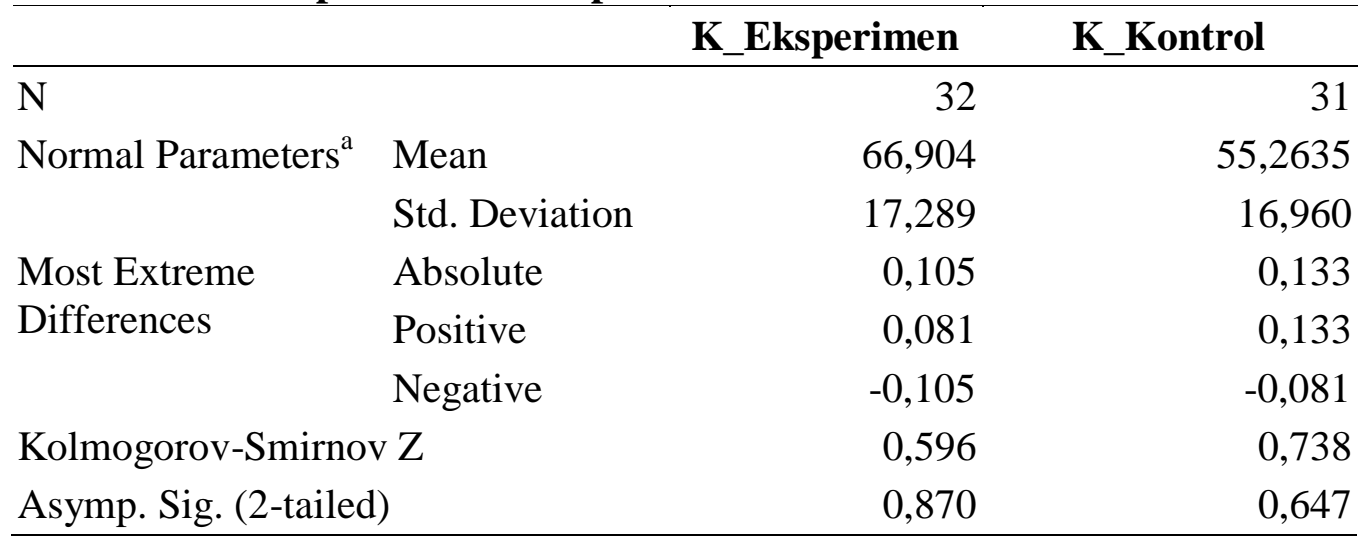

Berdasarkan Tabel 8 dapat dilihat bahwa pada kelas eksperimen nilai Asympt. Sig $(2-$ tailed $)=0,870>0,05=$ $\alpha$ yang berarti bahwa data hasil belajar matematika siswa pada kelas eksperimen berdistribusi normal. Sedangkan untuk kelas kontrol diperoleh nilai Asympt.

$\operatorname{Sig}(2-$ tailed $)=0,647>0,05=\alpha$ yang berarti bahwa data hasil belajar matematika siswa pada kelas kontrol berdistribusi normal.

Uji homogenitas digunakan statistik uji levene seperti yang disajikan pada Tabel 9.

Tabel 9. Hasil Analisis Uji Homogenitas Varians Data Posttest

\begin{tabular}{cccccc}
\hline Levene Statistic & df1 & & df2 & Sig. \\
\hline 0,120 & & 1 & & 61 & 0,730
\end{tabular}

Berdasarkan Tabel 9. dapat dilihat bahwa nilai nilai Sig. $=0,730>0,05=\alpha$ sehingga dapat disimpulkan bahwa kelas eksperimen dan kelas kontrol memiliki varians yang sama. Selanjutnya mengetahui pengaruh model pembelajaran kooperatif tipe STAD terhadap hasil belajar matematika siswa tersaji pada Tabel 10 berikut.

Tabel 10. Hasil Analisis Uji Hipotesis Independent Samples Test

\begin{tabular}{lcccccc}
\hline & \multicolumn{2}{c}{$\begin{array}{c}\text { Levene's Test for } \\
\text { Equality of Variances }\end{array}$} & \multicolumn{3}{c}{ t-test for Equality of Means } \\
\cline { 2 - 7 } & F & Sig. & t & df & \multicolumn{1}{c}{$\begin{array}{c}\text { Sig. } \\
\text { (2-tailed) }\end{array}$} \\
\hline Equal variances assumed & 0,120 & 0,730 & 2,697 & 61 & 0,009 \\
Equal variances not assumed & & & 2,698 & 60,99 & 0,009 \\
\hline
\end{tabular}

Berdasarkan Tabel 10. hasil analisis uji-t terlihat bahwa $1 / 2$ dari nilai Sig $(2-$ tailed $)$ untuk asumsi varians yang sama lebih kecil dari $\alpha=0,05(1 / 2$ $\times 0,09=0,0045<0,05)$ sehingga disimpulkan bahwa terdapat pengaruh yang signifikan antara model pembelajaran kooperatif tipe STAD terhadap hasil belajar matematika siswa kelas VII SMP Kesehatan Mandonga. 


\section{PEMBAHASAN}

Penelitian ini dilaksanakan selama tujuh kali pertemuan. Pertemuan pertama sampai ke enam dilaksanakan pembelajaran pada kelas eksperimen dan kelas kontrol, dengan materi yang diajarkan adalah "Bilangan Pecahan" sedangkan pada pertemuan ketujuh dilaksanakan posttest.

Pada pertemuan pertama di kelas eksperimen, pertama-tama dilakukan kegiatan pendahuluan yang meliputi penyiapan logistik, pemberian apersepsi, penyampaian tujuan pembelajaran, dan pemberian motivasi. Setelah kegiatan pendahuluan dilakukan, kemudian dilanjutkan pada kegiatan inti yakni, pemberian materi secara singkat dan jelas, kemudian dilakukan pembagian kelompok, dengan setiap kelompok beranggotakan 4-5 orang siswa. Setelah pembagian kelompok, siswa diarahkan untuk berkumpul dengan kelompoknya masing-masing.Setalah itu setiap kelompok diberikan LKS untuk dikejakan dengan teman kelomponya. Pada tahap ini, guru berperan memberi pengarahan dan bimbingan kepada siswa melalui penjelasan atau pertanyaan yang mengarah pada penyelesaian masalah bila diminta langsung oleh siswa. Setelah semua kelompok telah selesai mengerjakan LKS yang telah diberikan sesuai dengan jangka waktu yang ditentukan, beberapa siswa dipilih mewakili kelompoknya untuk tampil di depan kelas mempresentasikan hasil kerja kelompoknya untuk ditanggapi oleh kelompok lain. Guru berperan memandu jalanya diskusi, meluruskan jika ada jawaban siswa yang keliru dan membantu siswa dalam mengambil kesimpulan alterntaif jawaban yang paling benar. Diakhir pertemuan, guru membimbing siswa membuat kesimpulan dari materi yang telah dipelajari
Menerapkan model pembelajaran kooperatif tipe STAD dalam pembelajaran tentunya bukan hal yang mudah. Banyak kendala-kendala yang di hadapi oleh guru dan siswa sehingga menghambat kegiatan pembelajaran. Pada saat pembelajaran melalui tahapantahapan model pembelajaran kooperatif tipe STAD guru kesulitan dalam mengorganisir waktu. Guru dan siswa seharusnya konsisten dalam pengaturan waktu sesuai dengan perhitungan alokasi waktu dalam RPP. Kenyataanya dalam setiap tahapan-tahapan pembelajaran selalu mengalami penguluran waktu sehingga ada beberapa tahapan yang tidak sempat dilaksanakan karena waktu yang terbatas.

Berdasarkan pertemuan pertama pada kelas eksperimen, peneliti mengalami hambatan dimana siswa belum terbiasa dengan model pembelajaran yang baru yang diterapkan di dalam kelas mereka. Pada saat pembentukan kelompok tersebut, setiap siswa belum terbiasa untuk beradaptasi dengan teman kelompoknya yang baru serta belum terbiasa untuk bekerja sama dalam kelompok dalam menyelesaikan masalah yang diberikan oleh guru pada saat pemberian LKS. Pelaksanaan pembelajaran pada pertemuan kedua sampai pertemuan keenam mengalami peningkatan yang baik, dimana siswa maupun guru perlahan-lahan sudah bisa menyesuaikan dengan model pembelajaran yang digunakan pada saat pembelajaran berlangsung yakni model pembelajaran kooperatif tipe STAD, dengan sebelumnya telah merefleksi kekurangan pada saat kegiatan pembelajaran pertemuan pertama.

Berdasarkan hasil pengamatan pada kelas eksperimen pada pertemuan pertama menunjukan sebagian besar siswa sudah memiliki sikap dapat 
dipercaya, teliti, menghargai, tanggung jawab individu, tanggung jawab sosial, adil dan peduli. Dari setiap pembelajaran juga diketahui beberapa siswa sudah memiliki keterampilan sosial yang baik, dimana mereka mau bekerja sama dalam pembelajaran kelompok walaupun ada sebagian siswa kurang aktif dalam kelompoknya, namun hal ini dapat diatasi dengan baik karena pada dasarnya karakter siswa mau mendengarkan arahan dari guru. Nasehat dan bimbingan dari guru membuat sebagian siswa menunjukan peningkatan yang baik dalam perilaku dan keterampilan sosial mereka, diantaranya siswa yang tadinya kurang memiliki rasa tanggung jawab terhadap kelompoknya, telah menunjukan rasa tanggung jawab mereka berkat arahan dan masukan dari gurunya.Siswa juga lebih termotivasi untuk belajar dalam kelompok. Sebagian besar siswa juga telah dapat memberikan ide atau pendapat yang baik dalam proses pembelajaran kelompok.

Setelah dilaksanakan pembelajaran pada kelas eksperimen dengan model pembelajaran kooperatif tipe STAD dan kelas kontrol dengan model pembelajaran konvensional, diperoleh data hasil belajar matematika siswa kedua kelas. Berdasarkan hasil analisis deskriptif dari data yang diperoleh melalui tes hasil belajar matematika siswa diperoleh nilai rata-rata hasil belajar matematika siswa pada kelas eksperimen sebesar 66,90 sedangkan pada kelas kontrol sebesar 55,26 . Hal ini menunjukan bahwa ratarata hasil belajar matematika siswa pada kelas eksperimen lebih tinggi dari pada rata-rata hasil belajar siswa pada kelas kontrol. Rata-rata sebesar 66,90

\section{KESIMPULAN DAN SARAN}

Berdasarkan hasil penelitian dan pembahasan, dapat ditarik kesimpulan sebagai berikut: menunjukan bahwa nilai terbesar mewakili 32 orang siswa pada kelas eksperimen. Begitu pula rata-rata sebesar 55,26 menunjukkan bahwa nilai tersebut mewakili nilai 31 siswa pada kelas kontrol. Hal ini mengindikasikan dari segi rata-rata hasil belajar matematika siswa, pembelajaran dengan menggunakan model pembelajaran kooperatif tipe STAD lebih baik dari pada siswa yang diajar dengan model pembelajaran kooperatif konvensional. Berdasarkan segi keberagaman data, kelas eksperimen mempunyai varians sebesar 298,934 sedangkan pada kelas kontrol mempunyai varian 287,653. Dari hasil perhitungan varians tersebut dieroleh bahwa nilai varians pada kelas eksperimen lebih kecil dari pada nilai varians pada kelas kontrol.

Uji hasil hipotesis perbedaan ratarata hasil belajar matematika kelas eksperimen dan kontrol menunjukkan bahwa rata-rata hasil belajar matematika kelas eksperimen dan kelas kontrol berbeda secara nyata. Berdasarkan hasil uji hipotesis untuk melihat pengaruh penggunaan model pembelajaran kooperatif tipe STAD terhadap hasil belajar matematika siswa, terlihat bahwa terdapat pengaruh yang signifikan penggunaan model pembelajaran kooperatif tipe STAD terhadap hasil belajar matematika siswa. Hal ini didasarkan pada nilai signifikansi independent Sample Test yang lebih kecil dari 0,05 yang berarti $\mathrm{H}_{0}$ ditolak. Dengan kata lain, terdapat pengaruh yang signifikan penggunaan model pembelajaran kooperatif tipe STAD terhadap hasil belajar matematika siswa.

1. Rata-rata hasil belajar matematika siswa kelas VII $_{\mathrm{A}}$ yang diajar dengan model pembelajaran kooperatif tipe STAD pada materi bilangan pecahan 
sebesar 66,90, nilai tertinggi 95,00, dan nilai terendah adalah 28,50 .

2. Rata-rata hasil belajar matematika siswa kelas $\mathrm{VII}_{\mathrm{B}}$ yang diajar dengan model pembelajaran konvensional pada materi bilangan pecahan termaksud dalam kategori sedang dengan nilai rata-rata 55,26, untuk nilai tertinggi 85,71 , dan nilai terendah adalah 25,00.

3. Terdapat pengaruh yang signifikan penggunaan model pembelajaran kooperatif tipe STAD terhadap hasil belajar matematika siswa. Hal ini didasarkan pada nilai signifikansi uji Independent Sampel Test yang lebih kecildari 0,05 yang berarti $\mathrm{H}_{0}$ ditolak, sehingga dapat disimpulkan bahwa terdapat pengaruh yang signifikan penggunaan model pembelajaran kooperatif tipe STAD terhadap hasil belajar matematis siswa

Berdasarkan kesimpulan di atas, saran yang dapat diberikan adalah sebagai berikut:

1. Kepada para guru yang mengajar mata pelajaran matematika khususnya di

\section{DAFTAR PUSTAKA}

Arikunto, s. 2015. Prosedur Penelitian Suatu Pendekatan Praktik. Yogiakarta. Rineka Cipta.

Candiasa, I Made. 2015. Pengaruh model pembelajaran kooperatif tipe STAD dan Motivasi Berprestasi Terhadap Hasil Belajar Matematika Siswa Kelas VI SD Gugus Dewi Sartika. Journal Program Pascasarjana Universitas Pendidikan Ganesha Program Studi Penelitian dan Evaluasi Pendidikan, 5 (1): 10.

Isjoni. 2013. Pembelajaran Kooperatif Meningkatkan Kecerdasan Komunikasi Antara Peserta Didik. Yogyakarta: Pustaka Belajar.
SMP Kesehatan, sekiranya dapat menggunakan model pembelajaran kooperatif tipe STAD sebagai salah satu alternatif yang dapat digunakan dalam pembelajaran matematika untuk meningkatkan proses aktivitas siswa dan hasil belajar matematika siswa.

2. Perlu diadakan penelitian yang sejenis dengan cakupan materi matematika yang lain dan yang lebih luas untuk mengembangkan pembelajaran kooperatif tipe STAD dalam upaya meningkatkan hasil belajar matematika siswa.

3. pelaksanaan pembelajaran yang kurang maksimal, dan ini merupakan pengalaman pertama bagi peneliti dalam mengajar, oleh karenanya peneliti berharap kepada mahasiswa yang akan melakukan penelitian agar penggunaan strategi dapat dikuasai terlebih dahulu, sehingga dalam proses mengajar benar-benar dapat dioptimalkan.

Jihad, Asep. Haris, Abdul. 2013. Evaluasi Pembelajaran. Yogyakarta: Multi Pressindo.

Rusman. 2012. Model-Model Pembelajaran Mengembangkan Profesionalisme Guru Edisi Kedua. Bandung: Raja Grafindo Persada.

Shoimin, Aris 2016. 68. Model Pembelajaran Inovatif dalam Kurikulum 2013. Yogyakarta: ArRuzz Media.

Sudjana. 2005. Metoda Statistika. Bandung: Tarsito.

Sugiyono. 2016. Metode Penelitian Kuantitatif Kualitatif dan $R \& D$. Bandung: Alfabeta. 